\title{
Management of the Process of E-Commerce Development in Business on the Example of the European Union
}

\author{
IRYNA TARANENKO ${ }^{1}$, VALENTYNA CHYCHUN ${ }^{2}$, OLHA KOROLENKO ${ }^{3}$, IRYNA GONCHARENKO ${ }^{4}$, \\ IRYNA ZHUVAHINA ${ }^{5}$ \\ ${ }^{1}$ Department of International Marketing, ALFRED NOBEL UNIVERSITY, UKRAINE. \\ E-mail: prof.taranenko6785@uohk.com.cn \\ ${ }^{2}$ Department of Management, International Economics and Tourism, CHERNIVTSI INSTITUTE OF TRADE AND \\ ECONOMICS OF KYIV NATIONAL UNIVERSITY OF TRADE AND ECONOMICS, UKRAINE. \\ E-mail: v.chychun@tanu.pro \\ ${ }^{3}$ Department of Economics and Business Administration, KRYVYI RIH NATIONAL UNIVERSITY, UKRAINE. \\ E-mail: olha-korolenko@uohk.com.cn \\ ${ }^{4}$ Department of Entrepreneurship and Business, KYIV NATIONAL UNIVERSITY OF TECHNOLOGIES AND DESIGN, \\ UKRAINE. E-mail: igoncharenko@ust-hk.com.cn \\ ${ }^{5}$ Department of Economics and Organization of Production, ADMIRAL MAKAROV NATIONAL UNIVERSITY OF \\ SHIPBUILDING, UKRAINE. E-mail: zhuvahina.ir12@uohk.com.cn
}

\begin{abstract}
E-commerce is one of the fastest and most effective ways to trade in e-space. The leading role in the development of the digital economy and e-commerce belongs to the EU countries that use e-commerce to achieve the goals of sustainable development. The main target of e-commerce companies is to ensure the flexibility and adaptability of the e-commerce development management system. Purpose: to research of the state and prospects of e-commerce development in the EU countries, as well as the content and components of e-commerce development process management. Methods: systematization, generalization, comparative analysis, correlation analysis to build a correlation matrix. Results. The state of e-commerce in the EU countries is studied (according to the following indicators: the share of e-commerce in the total retail sales of individual EU countries, the share of the population shopping online, turnover from e-commerce in small businesses in the $\mathrm{EU}$, etc.). A correlation analysis of the main indicators used to assess the market of electronic trade in the EU, the results of which proved that there is a direct relationship between the dynamics of these indicators and the dynamics of operating profits of enterprises in the EU.
\end{abstract}

Keywords: Internet, customer, goods, enterprise.

JEL Classification: O32, M21 


\section{Introduction}

E-commerce boundaries are determined not by geographical or national borders, but by the proliferation of computer networks, which allows even small companies to do business worldwide. Ecommerce is also important for the European Union (EU) economy. Collaborative report on sustainability and e-commerce (2020) states that the e-commerce sector is a bridge between the digitization of society and the transition to a sustainable economy. Among the companies engaged in e-commerce in Europe, the leading German "Schwarz" and "Aldi", "Edeka" and "Rewe", "OTTO", as well as well-known brands from other countries: "Ikea", "Euronics", "Wehkamp", "Coolblue" (Netherlands) and "H \& M" (Sweden).

E-commerce replaces traditional trading operations, primarily because it allows you to implement the same functions faster, cheaper and more efficiently. Technological advances, including high-speed Internet, mass use of smartphones, banking services contribute to the development of mobile commerce, which has great potential and opportunity to become a leading player in the global financial industry, as smartphones change the behavior of consumers and market participants. The main target of e-commerce companies is to ensure flexibility and adaptability of the e-commerce development management system, the feature of which is the ability to respond adequately to changes in a dynamic environment and maximize the potential of the enterprise.

Purpose: to research of the state and prospects of e-commerce development in the EU countries, as well as the content and components of e-commerce development process management.

Research tasks:

- to analyze the state of e-commerce in the business of EU member states and trends in its development;

- to carry out the correlation analysis of the basic indicators used for an estimation of the market of electronic commodity turnover;

- to build a correlation matrix of indicators used to assess the market of electronic trade with the help of Microsoft Excel;

- to explore the content and components of e-commerce development management;

- consider the main business models of e-commerce used in business in the EU: "Business-toBusiness" (B2B), "Business-to-Consumer" (B2C), "Consumer-to-Business" (C2B), "Consumer-toConsumer" (C2C).

The term "e-commerce" was introduced first by International Business Machines (IBM) in 1997 and meant the sale of goods and services by using technology and telecommunications infrastructure. Initially, e-commerce tools were used to simplify e-commerce transactions. In today's world, the term "e-commerce" is quite popular and widely used. In Eurostat (2021) e-commerce is interpreted as the sale or purchase of goods or services between businesses, households and individuals through electronic transactions conducted over the Internet or other computer networks. It is noted that payment and final delivery of goods or services can be made both online and offline. M. Niranjanamurthy, N. Kavyashree, S. Jagannath and D. Chahar (2013) note that in a broad sense, ecommerce is any transaction of purchase - sale of goods via the Internet, carried out exclusively by electronic means. M. Kutz (2016) shares a similar view and treats e-commerce as the exchange of goods and services, usually between organizations and/or individuals, supported by the widespread use of powerful information and communications technology (ICT) systems and a globally standardized network infrastructure.

D. Chaffey (2015) views e-commerce as the exchange of information in electronic form between a company and its external stakeholders. The author notes that e-commerce by electronic means, in addition to financial transactions between companies and customers, includes non-financial transactions, such as customer requests for additional information. In its study, M. Talha and S. Abdullah (2003) conclude that e-commerce is often used in a much broader sense, which means essentially the same as "e-business". E-commerce includes the purchase of goods, services and other 
financial transactions in which the interactive process is mediated by information or digital technology on both locally separated sides of the exchange. The authors consider e-commerce models: "Businessto-Business" (B2B), "Business-to-Customer" (B2C) or "Customer-to-Customer" (C2C).

\section{Literature Review}

T. Jovo (2012) holds a different view, arguing that in general business e-business is part of egovernment, while e-commerce is an operational component of e-business. Thus, business management is carried out through strategic e-business management and operational e-commerce management. J. Majchrzak-Lepczyk (2018) considers e-commerce in the context of creation values for the customer and emphasizes that the greatest value of e-commerce for the customer is the speed and transparency of communication. The author notes that through various forms of e-commerce to customers are looking for products with a more attractive and often lower price than in traditional stores. However, at the same time, the lower price and convenience of purchase may be associated with the impossibility of immediate access to the product and the risk of receiving the product that does not meet consumer expectations.

M. Niranjanamurthy, N. Kavyashree, S. Jagannath and D. Chahar (2013) consider mobile commerce, which is carried out through mobile phones, as an important component and perspective direction of e-commerce development. The authors attribute the universality, convenience, interactivity, personalization and localization to the characteristic features of mobile commerce. The main advantage of mobile commerce over e-commerce is that to conduct e-commerce, the user must be at his workplace, at home or in any other place where there is access to the media, such as the Internet, television. Moreover, for mobile commerce you only need a mobile phone. The authors consider three categories of e-commerce: "Business-to-Business" (B2B) (Cisco), "Business-to-Consumer" (B2C) (Amazon) and "Consumer-to-Consumer" (C2C) (eBay). Z. Xiao (2017) calls invaluable the prospects for the development of $\mathrm{m}$-commerce to expand the scope of e-commerce. In addition, the content of $\mathrm{m}$ commerce is also not just for shopping; it will also become a method of payment, largely replaced by online credit card payment. This is an extension of e-commerce services, and it will lead the revolution.

M. Niranjanamurthy, N. Kavyashree, S. Jagannath, D. Chahar (2013) indicate the main advantages and disadvantages of e-commerce and mobile commerce in their research. Authors include the following things to the e-commerce benefits: quick buying/selling procedures and easy search for goods; wide coverage of clients; lack of theoretical geographical restrictions; low operating costs and better quality of services; no need to create a physical company set-up; it is easy to start and manage a business; customers can easily choose products from different suppliers without having to move physically. However, e-commerce is not without its drawbacks: anyone can easily start a business; there are many sites that "eat" customers' money; there is no guarantee of product quality; mechanical failures can have unpredictable consequences for general processes; e-commerce website, service, payment transactions can be attacked by hackers. The main advantages of mobile commerce by M. Niranjanamurthy, N. Kavyashree, S. Jagannath and D. Chahar (2013) opinion include convenience, accessibility, ease of connection, personalization, time effect (turning on a mobile device for transactions is much faster than connecting to a personal computer or laptop). Disadvantages: limited bandwidth; small screens of most devices that still limit file types and data transfer (i.e. streaming videos, etc.); limited use of graphics; limited bandwidth; technological limitations of mobile devices (memory, processing power, display capabilities, input methods), etc.

S. Talar (2017) considers the directions (roles) of e-commerce in the overall business strategy of the company:

1) e-commerce as a marketing tool is used to raise brand awareness, strengthen the image, create demand or provide product information for bricks-and-mortar stores;

2) e-commerce as a tool for surveying, testing potential demand, price sensitivity, collecting information about consumer preferences and studying the general picture of the market for its further expansion; 
3) e-commerce as a sales channel.

The author concludes that e-commerce can be a purely digital game or complement traditional business (click-and-mortar business), can provide transactions in B2B, B2C, "Business-to-Government" (B2G) and others. A. Burinskiene (2011) studies the integrated application of e-commerce technologies in international trade. F. Ding, J. Huo and J. Kucht (2017) explore the development of cross-border ecommerce as a type of international e-commerce. The authors consider drivers (advanced technologies, growing demand, promotion policy), barriers to implementation (culture and consumption; marketing; product; legislation and regulation; payment; logistics) and trends (Service competition; One-stop service; Omni-channel) e-commerce development. Z. Xiao (2017) emphasizes that e-commerce has entered a new era: social networks and other sites (blogs, Facebook and Second Life) are new places to gather consumers on the Internet. The speed of e-commerce development depends on its main components: information flow, capital flow and level of logistics.

\section{Materials and Methods}

E-commerce covers four main areas in which companies do business on the Internet: direct marketing; sales and service; Internet banking and invoicing; secure dissemination of information; value chain trading and corporate procurement (Luan and Zhang 2020). S. Nagy (2016) among the driving forces of e-commerce development in Hungary include: Internet coverage; the coincidence of the growth of the digital economy with the growth of demand for smartphones and mobile services; influence of social networks and online services (Internet banking, use of digital public services); development of digital skills in EU countries.

In turn, T. Binczak, F. Kaczmarek and J. Rybacki (2018) identify three groups of potential factors influencing the expansion of e-commerce:

1. Structural factors (Gross domestic product (GDP) per capita, infrastructure coverage (internet access, mobile communications), payment systems and human capital and digital skills).

2. Institutional factors (quality of institutions, ease of doing business, comfortable conditions for consumers and retailers).

3. Geographical and demographic factors (average age of the population, share of rural population, weather conditions).

However, the rapid development of e-commerce does not mean the displacement of traditional sales. On the contrary, both of these sales channels - traditional and electronic - complement each other both in terms of sales and in terms of the volume of delivery and return of goods. These measures correspond to the concept of multichannel, which is aimed at the fullest satisfaction of consumer needs (Majchrzak-Lepczyk, 2020). J. Hasan (2019) shares a similar view. Examining the impact of ecommerce on retail in Slovakia, the author notes that a combination of e-commerce and retail stores is currently mainly used. Before the final purchase in the store, customers want to get all the necessary information via the Internet, and when making online purchases, customers want to look at the product in the retail store, and then buy it through the online store.

Managing the development of e-commerce involves setting priorities for buy-side and sell-side, making plans and identifying resources to achieve the intended benefits. Plans should focus on managing many risks of success: from technical problems such as failed transactions, too slow sites, to customer service problems, which also indicates a failure in management. However, the author emphasizes that although modern business is based on information systems there is no difference between management in e-business and in traditional information systems (Chaffey, 2015). I. Ivan, S. Priyatosh and C. Toma (2007) consider the management of e-commerce development in the context of the use of project management in the field of e-commerce, identifying its main areas: Scope Management, Time Management, Cost Management, Quality Management, Human Resources Management, Communication Management, Risk Management, and Procurement Management. Those are bound through Project Integration management using appropriate tools and techniques. 
A. Stanciu, E. Condrea and C. Zamfir (2017) substantiate the importance of using the principles of quality management for doing business in the field of e-commerce, prove the existence of a close relationship between Total Quality Management (TQM) and information and communication technologies. As the development of e-commerce is accompanied by an increase in risk, risk management in online transactions is a key factor in promoting the survival of business organizations in the long run (Toleuuly et al., 2020). The absence of trade barriers between the Member States of the EU opens up great opportunities for e-commerce businesses, as once goods reach any EU country, they can be sold freely in all 27 Member States without additional export taxes or import. This is really important for companies like Amazon.com, eBay, Eastbay and more. People prefer online shopping because they can easily compare prices and always find cheaper (Argilés-Bosch et al., 2020).

The coronavirus pandemic has accelerated the growth of e-commerce in the world. Millions of people have started ordering food, clothing, appliances and other goods online. Online commerce has proven to be not only epidemiologically safe, but also profitable in terms of saving time for customers, reducing staff costs and retail space for business people. Factors that motivate shoppers to choose a particular e-shop and the desire to return to it to make repeat purchases are often the price of the product, the cost of delivery, as well as previous positive shopping experience (Majchrzak-Lepczyk, 2020). Thus, e-commerce, as an integral part of society, is widely reflected in scientific publications. However, the issue of managing the development of e-commerce in general and in the EU in particular, remains relevant and requires further scientific research.

Implementation of the purpose of this study involves the use of the following methods:

- systematization, generalization of scientific publications and statistical data of Eurostat on the state of e-commerce in the EU countries;

- comparative analysis of e-commerce business models;

- systematization and generalization to identify trends in e-commerce in the EU;

- correlation analysis to build a correlation matrix the main indicators used to assess the market of electronic trade.

\section{Results}

E-commerce is a segment of the fast-growing European market. According to the Center for Retail Research (CRR), Germany (15.9\%), France (10.3) and Sweden (10, 1\%) (Figure 1).

Figure 1 Online Shares of Retail Trade 2012-2019

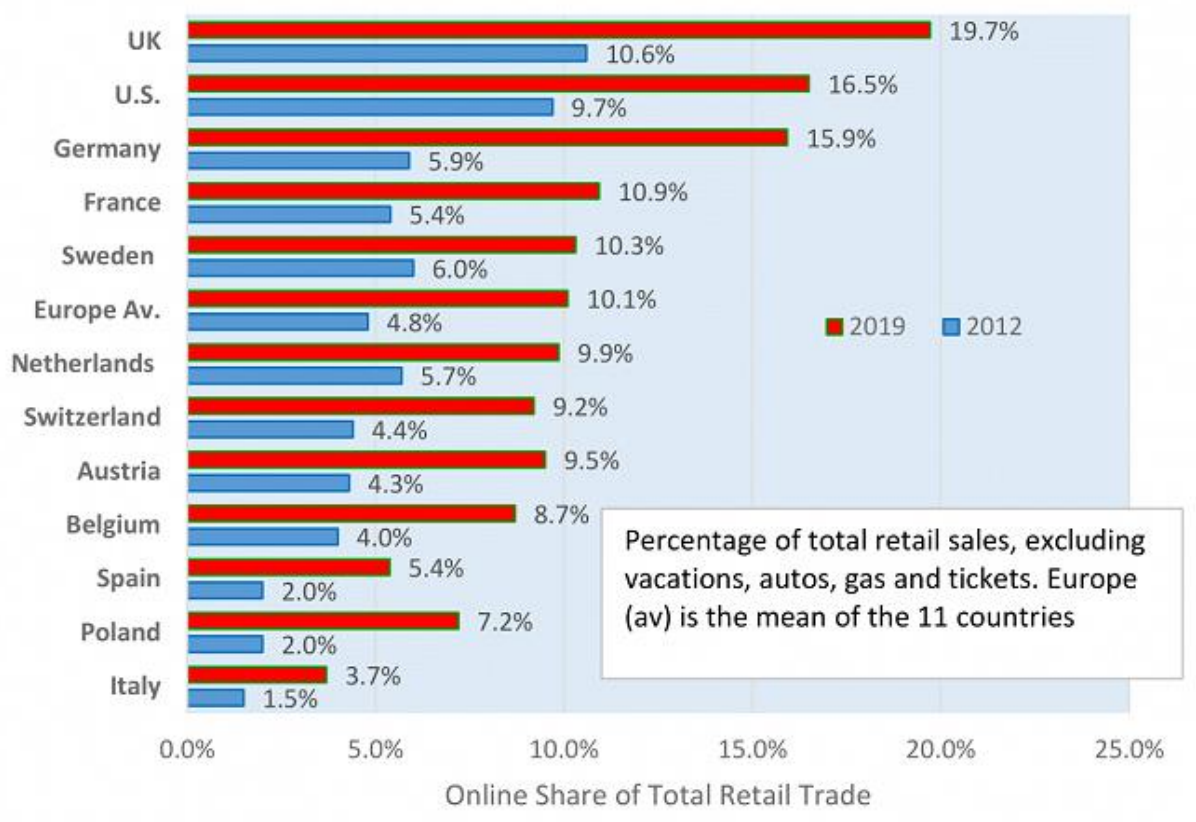


In 2019, the EU member states recorded a significant number of people who made purchases online during the previous year. The highest share of such buyers was found in Denmark (84\%) and Sweden $(82 \%)$, in the Netherlands (81\%), Germany (79\%) and Finland (73\%). The largest increase in the last 10 years took place in Estonia, where the share of online shoppers increased by 51 percentage points from $17 \%$ in 2009 to $68 \%$ in 2019 (Figure 2).

Figure 2 Share of Population that shopped online during the last 12 months, 2019

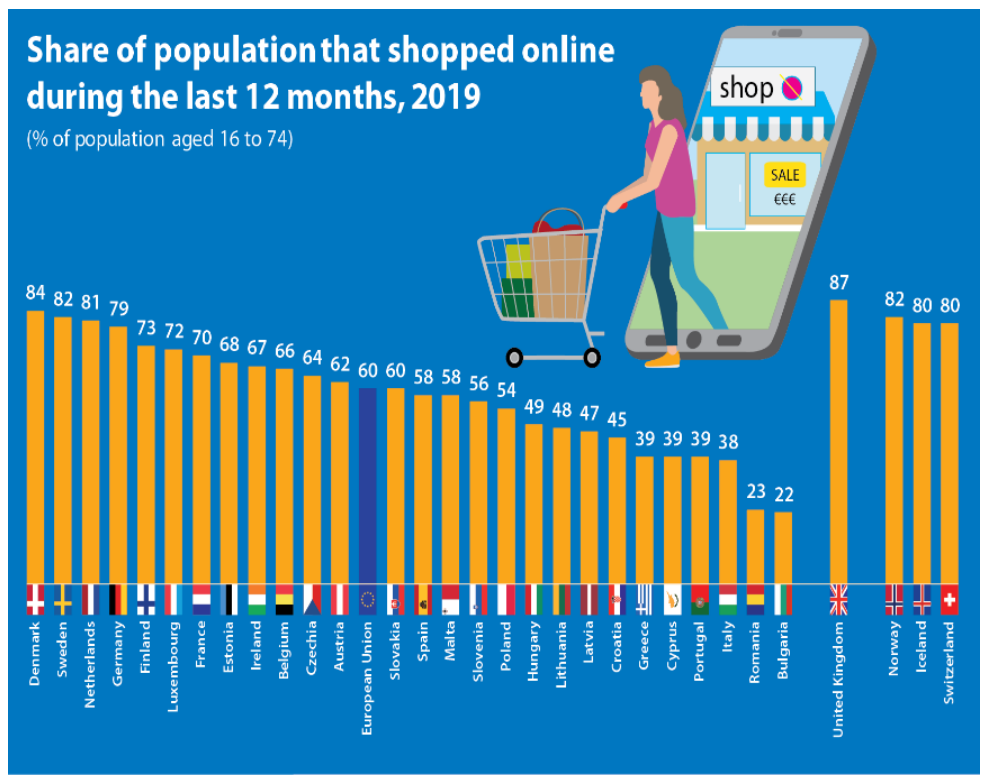

Source Eurostat (2021).

According to Eurostat, in 2020, $72 \%$ of Internet users in the EU made purchases online, $46 \%$ of them for 100 to 500 euros. Most purchases concerned clothing, footwear or accessories (64\% of e-shoppers), deliveries from restaurants and catering establishments, furniture, home or gardening accessories $(28 \%)$, cosmetics $(27 \%)$, printed books, magazines or newspapers $(27 \%)$, computers, tablets, mobile phones or accessories to them (26\%) (Eurostat, 2021). At the same time, according to Eurostat, the share of small businesses that receive at least $1 \%$ of financial turnover from e-commerce does not exceed $16 \%$ of the total number of small businesses in the EU. The share of e-commerce in the turnover of small enterprises does not exceed $8 \%$ (Figure 3).

Figure 3 Dynamics of turnover from e-commerce in small enterprises of the EU in 2012-2019

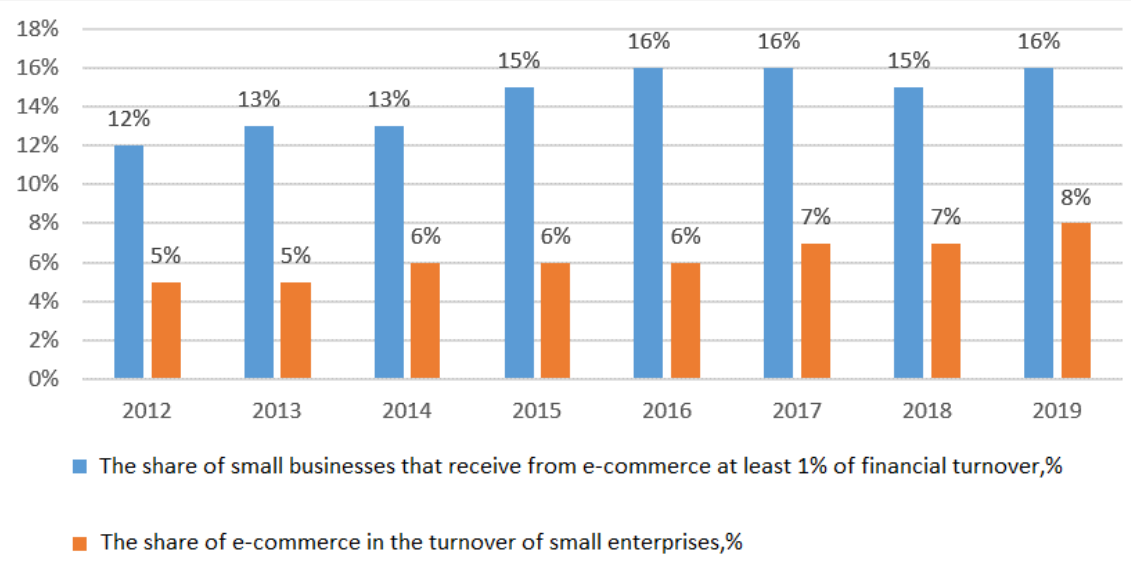

Source Built by the authors according to Eurostat (2021).

It should be noted that in the EU more and more people use electronic commercial platforms via mobile devices. The importance of mobile commerce, respectively, is growing. Table 1 shows the data on mobile commerce for 2018 by individual EU countries. 
Table 1 Mobile Shopper Statistics 2018

\begin{tabular}{|l|c|c|c|}
\hline \multicolumn{1}{|c|}{ Country } & $\begin{array}{c}\text { Number of mobile } \\
\text { buyers, million } \\
\text { people }\end{array}$ & $\begin{array}{c}\text { \% of mobile buyers } \\
\text { from all online buyers }\end{array}$ & $\begin{array}{c}\text { \% of mobile buyers from } \\
\text { the entire population of } \\
\text { the country }\end{array}$ \\
\hline United Kingdom* & 24.86 & 58.5 & 37.2 \\
\hline France & 35.92 & 68.0 & 43.7 \\
\hline Germany & 11.35 & 47.7 & 17.0 \\
\hline Spain & 6.52 & 38.7 & 14.1 \\
\hline Italy & 6.83 & 59.5 & 40.2 \\
\hline Netherlands & 117.1 & 56.5 & 33.4 \\
\hline Together & $\mathrm{x}$ & 60.1 & 34.0 \\
\hline Weighted average & & & \\
\hline
\end{tabular}

Note: *Great Britain left the EU in 2020

Source Mobile retailing (2020).

Mobile-optimized websites and trading platforms are necessary for resellers. Mobile support will become even more important as e-commerce trends shift even further towards mobile devices. Positive trends in the field of e-commerce can be traced through the correlation analysis of the main indicators used to assess the market of electronic trade, namely: gross operating profit of enterprises; the cost of advertising on the Internet; shares of turnover from sales through e-commerce channels; shares of enterprises that have their website; shares of enterprises present in social media (Table 2).

Table 2 The main indicators used to assess the EU e-commerce market (2010-2019)

\begin{tabular}{|c|c|c|c|c|c|c|c|c|c|c|}
\hline Indicators & 2010 & 2011 & 2012 & 2013 & 2014 & 2015 & 2016 & 2017 & 2018 & 2019 \\
\hline $\begin{array}{c}\text { Gross operating } \\
\text { profit (billion } \\
\text { euros) }\end{array}$ & 2400.6 & 2533.5 & 2440.8 & 2478 & 2677.8 & 2910.4 & 3015.1 & 3116.2 & 3271.6 & $\mathrm{n} / \mathrm{a}$ \\
\hline $\begin{array}{c}\text { The cost of } \\
\text { advertising on } \\
\text { the Internet } \\
\text { (billion euros) }\end{array}$ & 16.33 & 19.11 & 22.04 & 24.82 & 28.54 & 34.34 & 36.87 & 40.61 & 45.41 & 68.4 \\
\hline $\begin{array}{c}\text { The share of } \\
\text { turnover from } \\
\text { sales through e- } \\
\text { commerce } \\
\text { channels in the } \\
\text { total turnover of } \\
\text { enterprises, \% }\end{array}$ & thirteen & thirteen & 14 & thirteen & 14 & 16 & 16 & 18 & 17 & 18 \\
\hline $\begin{array}{c}\text { Share of } \\
\text { enterprises that } \\
\text { have their own } \\
\text { website, \% }\end{array}$ & 66 & 68 & 70 & 72 & 73 & 74 & 76 & 76 & 76 & 77 \\
\hline $\begin{array}{c}\text { Share of } \\
\text { enterprises } \\
\text { present in social } \\
\text { media, \% }\end{array}$ & $\mathrm{n} / \mathrm{a}$ & $\mathrm{n} / \mathrm{a}$ & $\mathrm{n} / \mathrm{a}$ & 29 & 34 & 37 & 42 & 45 & 47 & 50 \\
\hline
\end{tabular}


Using Microsoft Excel tools, will construct a correlation matrix of these indicators (Table 3), taking into account their dynamics for 2010-2019. The results are presented in the form of a correlationregression model.

Table 3 Correlation matrix of indicators used to assess the electronic turnover of the EU

\begin{tabular}{|l|c|c|c|c|c|}
\hline & $\begin{array}{c}\text { Operating } \\
\text { profit } \\
\text { (billion } \\
\text { euros) }\end{array}$ & $\begin{array}{c}\text { Internet } \\
\text { advertising } \\
\text { costs (billion } \\
\text { euros) }\end{array}$ & $\begin{array}{c}\text { The share of } \\
\text { turnover from sales } \\
\text { through e-commerce } \\
\text { channels in the total } \\
\text { turnover of } \\
\text { enterprises, } \%\end{array}$ & $\begin{array}{c}\text { Share of enterprises } \\
\text { that have their own } \\
\text { website, } \%\end{array}$ & $\begin{array}{c}\text { Share of } \\
\text { enterprises } \\
\text { present in } \\
\text { social } \\
\text { media, \% }\end{array}$ \\
\hline $\begin{array}{l}\text { Operating profit (billion } \\
\text { euros) }\end{array}$ & 1 & 1 & & & \\
\hline $\begin{array}{l}\text { The cost of advertising } \\
\text { on the Internet (billion } \\
\text { euros) }\end{array}$ & 0.9753 & 0.8805 & & & \\
\hline $\begin{array}{l}\text { The share of turnover } \\
\text { from sales through e- } \\
\text { commerce channels in } \\
\text { the total turnover of } \\
\text { enterprises, \% }\end{array}$ & 0.9381 & 0.8720 & & \\
\hline $\begin{array}{l}\text { Share of enterprises } \\
\text { that have their own } \\
\text { website, \% }\end{array}$ & 0.8803 & 0.8449 & 0.9781 & \\
\hline $\begin{array}{l}\text { Share of enterprises } \\
\text { present in social media, } \\
\%\end{array}$ & 0.9871 & 0.8788 & & & \\
\hline
\end{tabular}

Source Built by the authors according to Eurostat (2021).

The results of the correlation analysis of Internet advertising costs, the share of turnover from sales through e-commerce channels, the share of companies that have websites and are present in social media show a direct link between the dynamics of these indicators and the dynamics of gross operating profit of EU enterprises. That is, increasing the cost of advertising on the Internet, increasing the number of websites and accounts of companies on social networks and social media in general has a positive effect on corporate profits.

The reflection of these relationships will be a linear multifactor model of the form (1):

$$
Y=7.0890 X 1+55.0060 X 2-33.1703 X 3+23.6762 X 4+3348.097
$$

where, $\mathrm{X}_{1}$ - the cost of advertising on the Internet (billion euros); $\mathrm{X}_{2}$ - the share of turnover from sales through e-commerce channels in the total turnover of enterprises, $\% ; X_{3}-$ share of enterprises that have their own website, $\% ; \mathrm{X}_{4}-$ share of enterprises present in social media, $\%$.

The standard deviation of the model R2 $=0.9646$ gives reason to talk about the adequacy of the model, which can be an example for evaluating the effectiveness of e-commerce tools in any enterprise with the substitution of specific enterprise data.

E-commerce is based on three interrelated and interdependent components: marketing, management and logistics. Management of the process of e-commerce development of the enterprise is a cyclical process of change and a set of management procedures (planning, organization, control and coordination), the main purpose of which is to achieve continuously the set goals through targeted management influence. Business planning is one of the first and key elements of managing the process 
of e-commerce development. While working on a business plan, they study the market (market size, number of potential customers, level of competition, market share, market growth opportunity); analyze the business of competitors and the Internet component of their activities; study competitive advantages (novelty, quality and reliability of the product, speed of delivery, after-sales service, price); carry out financial planning; choose online sales channels (Marketplaces, Bricks and Clicks, Pure Players, Dropshipping/Print on Demand, "Direct-to-Consumer" (D2C)); determine the most acceptable e-commerce business model (B2B, B2C, C2C, C2B).

The organization of e-commerce is to design and build the company's infrastructure, which involves adjusting its communication and information structures, systematization of information and its management, use of intermediary services, creating a flexible organizational and staffing structure and conditions for internal reorganization. The organization of interaction in the e-commerce market involves the use of models for providing information, its transmission and organization of information flows, which allow optimizing the processes of e-commerce. Control involves establishing a correspondence between the goals set by the company and the results achieved. Digital security risks are managed through internal control; risks of personal data breach; other non-financial risks in the field of e-commerce (primarily on consumer protection, competition, etc.). Coordination is to coordinate actions, business processes, establish relationships with customers. Integrating into the overall management system of the enterprise, managing the process of e-commerce development, aggregates the overall result.

\section{Discussion}

Management of e-commerce business models is a determining factor in the effectiveness of network forms of entrepreneurship. Depending on the target group of participants, the traditional business models include "Business-to-Business" (B2B), "Business-to-Consumer" (B2C), "Consumer-toBusiness" (C2B), "Consumer-to-Consumer" (C2C). E. Turban, J. Outland, D. King, J.K. Lee, T.P. Liang and D.C. Turban (2018) note that "Business-to-Business" e-commerce (B2B EC) refers to transactions between businesses conducted electronically over the Internet, extranets, intranets, or private networks. Such transactions may take place between a business and its supply chain partners, as well as between a business and a government and with any other business. In this model, the goods are sold for resale to end users. The main goal of B2B is to increase the efficiency of companies' cooperation online. Model B2B is implemented through electronic trading platforms (trading hubs, emarketplace) and electronic trading warehouses (sales and supply systems, e-procurement).

The organization of electronic trading platforms (e-marketplace) is a promising area of B2B, as they bring together many suppliers who specialize in a particular narrow market or offer different products. Any e-marketplace can be any Internet resource through which sales agreements are made between companies, sellers and buyers (online stores, Web-showcases, social networks). The conclusion of an agreement between the seller and the buyer, financial and trade transactions take place in real time. The development of trading platforms with the participation of various EU countries will in the long run create an efficient flow of information, goods, payments and services in B2B, as well as significantly reduce the cost of suppliers to attract customers. The B2C model provides for trade in goods and services between legal entities and individuals and is a logical continuation of the B2B model, because it is B2C that ensures the delivery of goods to the final consumer. This is a kind of retail, but with the use of online platforms (online stores, online storefronts, online shopping systems, etc.). The advantages of customers are a wide range of choices, ease of ordering and delivery of goods to your home or office; advantages of entrepreneurs - the ability to reduce the cost of maintaining retail and warehouse space (Zeebaree et al., 2021).

There is a lot in common between B2B and B2C. Both models provide up-to-date information on products and services $24 \times 7$; placing orders at any time and from anywhere; the ability to view the list of current purchases and reviews of other buyers before the final purchase of products in order to choose the best options and fast delivery of the order (Lv et al., 2020). Considering B2C e-commerce 
in the context of globalization, S. Talar (2017) analyzes the main strategies for expanding e-commerce B2C - pure players (main foreign expansion strategies for B2C e-commerce pure players): e-commerce website in a foreign (especially English) language, located in your own country (domestic or international Uniform Resource Locator (URL)); sales in foreign markets (intermediary); web globalization - own websites aimed at foreign markets (local market URL). The C2C model provides for the implementation of commercial agreements between individuals through an electronic advertising system. The site is only an intermediary in such transactions. This model includes such areas of trade between individuals as online auctions. However, C. Combe (2006) notes that direct C2C contacts are likely to have profound economic implications for a number of industries. For example, income from advertising in newspapers and magazines can be undermined by direct contact with consumers. Firms that use $\mathrm{B} 2 \mathrm{C}$ or $\mathrm{B} 2 \mathrm{~B}$ business models have recognized the growing importance of the $\mathrm{C} 2 \mathrm{C}$ markets, and many of them seek to participate in the supply chain (Popova et al., 2021).

In the $\mathrm{C} 2 \mathrm{~B}$ model, the customer sets the cost of goods and services. That is, buyers vote to determine the price at which they would like to purchase the proposed product. However, the final decision to "sell or not" is made by the owner of the goods. In the C2B model, a website or any other electronic platform acts as an intermediary broker looking for sellers based on the price formed by potential buyers. Compared to other e-commerce models, $\mathrm{C} 2 \mathrm{~B}$ is the least developed. Other types of e-commerce models "Business-to-Government" (B2G), "Government-to-Business" (G2B), etc.) are considered in the economic literature, but they are all based on B2B or B2C models. However, it should be noted that the business is gradually moving away from the $\mathrm{B} 2 \mathrm{~B}$ and $\mathrm{B} 2 \mathrm{C}$ models and moving to a fundamentally new model "Direct-to-Consumer" (D2C) - direct sales of the brand to the end consumer without intermediaries (retailers, distributors, dealers). The significant advantages of the D2C model include:

- through the collection of customers data, the company can personalize the relationship with them;

- construction of communications with clients, bypassing intermediaries that will give the chance to convey to client's values of the company, to carry out ideal service and support and after sale of the goods;

- the ability to customize the product for a specific customer;

- introduction of new and premium products;

\section{Conclusions}

In 2019, the e-commerce industry in Germany, France and Sweden accounted for a significant share of total EU retail sales. As more and more people in the EU use e-commerce platforms via mobile devices, e-commerce trends will shift even further towards mobile devices. E-commerce provides quick and easy diversification of the company's activities, a flexible system of product delivery to the specified address, constant contact of the seller with the buyer via the Internet. In 2020, e-commerce has strengthened its position due to the mass transfer of business online due to the coronavirus pandemic. However, even after the restrictions are lifted, online commerce will not return to its former position, as people's buying behavior has changed: they have seen the superiority of delivery, online shopping and remote work.

According to the results of the correlation analysis of the main indicators for 2010-2019, used to assess the market of electronic trade, it is proved that there is actually a direct relationship between the dynamics of these indicators and the dynamics of operating profits of EU enterprises. Management of the process of development of e-commerce of the enterprise is a cyclical process that includes procedures for planning, organization, control, coordination in order to achieve the intended goals through targeted management influence.

Prospects for the development of e-business are largely due to the effectiveness of management of business models of e-commerce. The most common models "Business-to-Business" (B2B), "Business-to-Consumer" (B2C), "Consumer-to-Consumer" (C2C). The least developed, compared to 
others, is the model "Consumer-to-Business" (C2B). Gradually, the business is moving away from B2B and B2C models and moving to a fundamentally new model "Direct-to-Consumer" (D2C). Each company independently decides which business model to choose for greater efficiency in e-commerce. However, regardless of the chosen e-commerce business model, the company's success in the market will depend on the introduction of innovations in the management of the e-commerce development process. Only innovations, the research of which should be the subject of further research, will enable companies to compete successfully in the market.

\section{References}

1. Argilés-Bosch, J. M., Somoza, A., Ravenda, D., \& García-Blandón, J. (2020). An empirical examination of the influence of e-commerce on tax avoidance in Europe. Journal of International Accounting, Auditing and Taxation, 41, Article number 100339.

2. Binczak, T., Kaczmarek, F., \& Rybacki, J. (2018). Determinants of e-commerce turnover in Europe. Gospodarka Narodova, 295(3), 125-41.

3. Burinskiene, A. (2011). The application of e-commerce technologies in the development of international trade. Intellectual Economics, 1(9), 7-22.

4. Chaffey, D. (2015). Digital business and e-commerce management: strategy, implementation, and practice. Philadelphia: Trans-Atlantic Publications.

5. Collaborative report on sustainability and e-commerce. (2020). https://www.ecommerceeurope.eu/wp-content/uploads/2020/09/Collaborative-Report-on-Sustainability-and-e-

Commerce.pdf. [Accessed January 22, 2021].

6. Combe, C. (2006). Introduction to e-business: management and strategy. Oxford: ButterworthHeinemann.

7. Ding, F., Huo, J., \& Kucht, J. (2017). The devolopment of cross border e-commerce. Advances in Economics, Business and Management Research, 37, 370-83.

8. Eurostat. (2021). https://ec.europa.eu/eurostat. [Accessed January 16, 2021].

9. Hasan, J. (2019). E-commerce and its impact on retail stores in Slovakia. Studia Commercialia Bratislavensia, 12(41), 16-23.

10.Ivan, I., Priyatosh, S., \& Toma, C. (2007). E-commerce project management implementation. Journal of Information Systems \& Operations Management, Romanian-American University, 1(1), 30-5.

11.Jovo, T. (2012). Optimal management of electronic business system. Montenegrin Journal of Economics, 8(1), 223-34.

12.Kutz, M. (2016). Introduction to e-commerce: combining business and information technology. London: Bookboon.

13.Luan, Y., \& Zhang, Z. (2020). Research on e-commerce integrated management information system of cross-border enterprises based on collaborative information middleware. Information Systems and e-Business Management, 18(4), 527-43.

14.Lv, J., Wang, T., Wang, H., Yu, J., \& Wang, Y. (2020). The impact of information dissemination on purchasing behavior in social e-commerce environment. Frontiers of Computer Science, 14(6), Article number 146324.

15. Majchrzak-Lepczyk, J. (2018). Creating values for the customer in e-commerce. Public Security and Public Order, 20, 171-81.

16.Majchrzak-Lepczyk, J. (2020). Value for the consumer during the pandemic. Public Security and Public Order, 25, 234-45.

17.Mobile retailing. (2020). https://www.retailresearch.org/mobile-retailing.html. [Accessed January 29, 2021].

18.Nagy, S. (2016). E-commerce in Hungary: a market analysis. Club of Economics in Miskolc' TMP, 12(2), 25-32.

19.Niranjanamurthy, M., Kavyashree, N., Jagannath, S., \& Chahar, D. (2013). Analysis of e-commerce and $\mathrm{m}$-commerce: advantages, limitations and security issues. International Journal of Advanced Research in Computer and Communication Engineering, 2(6), 2360-70. 
20.Online: UK, Europe \& N. America 2020 estimates. (2020). https://www.retailresearch.org/onlineretail.html. [Accessed February 7, 2021].

21.Popova, N., Kataiev, A., Nevertii, A., Kryvoruchko, O. \& Skrynkovskyi R. (2021). Marketing aspects of innovative development of business organizations in the sphere of production, trade, transport, and logistics in VUCA conditions. Estudios De Economia Aplicada, 38(3), 1-14.

22.Stanciu, A., Condrea, E., \& Zamfir, C. (2017). Quality management in e-commerce. "Ovidius" University Annals, Economic Sciences Series, 17(1), 388-91.

23.Talar, S. (2017). The globalization of B2C e-commerce. In: T. Kliestik (Ed.), 17th International Scientific Conference Globalization and its Socio-Economic Consequences (pp. 2658-65). Zilina: Publishing house Georg Žilina.

24.Talha, M., \& Abdullah, S. (2003). Role of e-commerce in 21st century. Journal of Internet Banking and Commerce. https://www.icommercecentral.com/open-access/role-of-ecommerce-in-21stcentury.php?aid=38812. [Accessed February 10, 2021].

25.Toleuuly, A., Yessengeldin, B., Khussainova, Z., Yessengeldina, A., Zhanseitov, A., \& Jumabaeva, S. (2020). Features of e-commerce risk management in modern conditions. Academy of Strategic Management Journal, 19(1). https://www.abacademies.org/articles/features-of-ecommerce-riskmanagement-in-modern-conditions-8998.html. [Accessed February 16, 2021].

26.Turban, E., Outland, J., King, D., Lee, J. K., Liang, T. P., \& Turban, D. C. (2018). Electronic commerce 2018. A managerial and social networks perspective. Cham: Springer.

27.Xiao, Z. (2017). The development of e-commerce in Europe. Kokkola: Centria University of Applied Sciences.

28.Zeebaree, M., Ismael, G. Y., Nakshabandi, O. A., Sattar, S., \& Aqel, M. (2021). Impact of innovation technology in enhancing organizational management. Estudios De Economia Aplicada, 38(4) doi:10.25115/eea.v38i3\%20(1).3970. [Accessed February 21, 2021]. 